Original Research Article

\title{
A comparative study of the antidepressant effect of ondansetron and granisetron on Albino mice
}

\author{
Mansi J. Shah, Geetha M.*, Rahul H. D., Shashikala G. H.
}

Department of Pharmacology, JJMMC, Davangere, Karnataka, India

Received: 15 October 2017

Revised: 27 October 2017

Accepted: 07 November 2017

*Correspondence to:

Dr. Geetha M.,

Email: drgeethamijmmc@ gmail.com

Copyright: (C) the author(s), publisher and licensee Medip Academy. This is an openaccess article distributed under the terms of the Creative Commons Attribution NonCommercial License, which permits unrestricted noncommercial use, distribution, and reproduction in any medium, provided the original work is properly cited.

\begin{abstract}
Background: Ondansetron and granisetron are selective 5-HT receptor antagonists used as antiemetics. The present study as aimed at comparing the antidepressant activity of ondansetron and granisetron in animal experimental models.

Methods: The study was done after obtaining approval from the institutional animal ethical committee of JJM Medical college, Davangere and CPCSEA. A total of 24 mice of either sex and of weight between $20-40 \mathrm{~g}$ were included in the study. The antidepressant activity of ondansetron and granisetron was evaluated in mice using forced swim test model (FST) and tail suspension testmodel(TST). In both the experimental models animals were divided into 4 groups and received the following drugs- Group 1 (control) - normal saline $10 \mathrm{mg} / \mathrm{kg}$ i.p, Group 2 (standard)-fluoxetine $10 \mathrm{mg} / \mathrm{kg}$ i.p, Group 3(test drug 1), ondansetron $2 \mathrm{mg} / \mathrm{kg}$ i.p, Group 4 (test drug 2)- granisetron $0.5 \mathrm{mg} / \mathrm{kg}$ i.p. The duration of immobility was noted and compared amongst the 4 groups in both the models $60 \mathrm{~min}$ after drug administration. The observations were analysed using ANOVA (one way) and post hoc Tukey's test.

Results: The test drugs showed significant reduction in duration of immobility in both the models. In FST and TST models, granisetron $(0.5 \mathrm{mg} / \mathrm{kg}$ i.p) showed a significant reduction in immobility period of $10.33 \mathrm{sec}$ and $67 \mathrm{secs}$ respectively when compared to ondansetron $(2 \mathrm{mg} / \mathrm{kg}$ i.p) and the standard drug fluoxetine (10mg/kg i.p).

Conclusions: The results of study suggest that granisetron may be useful as a potential candidate for treatment of depression. Hence further animal studies with different model for depression and clinical studies should be conducted in order to choose the better drug for treatment PONV which is often associated with depression.
\end{abstract}

Keywor ds: Antidepressants, Granisetron, Ondansetron

\section{INTRODUCTION}

Depression is a mental disorder, defined as depressed mood on a daily basis for a minimum duration of 2 weeks. It is an affective disorder characterized by sadness, apathy, changes in sleep pattern, impaired concentration, feeling of shame or guilt, thoughts of dying or death. ${ }^{1}$

The WHO has ranked depression fourth in a list of the most urgent health problems worldwide. An estimated $5.8 \%$ of men and $9.5 \%$ of women experience depressive episodes in their lifetime and $60 \%$ of death toll due to suicides is due to depressive illness. ${ }^{2}$ In India the prevalence of depression is 31.2 per 1000 population. ${ }^{3}$

The interaction of genetic and environmental risk factors leads to depression. The main symptoms of depression are due to functional deficiency in the level of monoaminerg ic neurotransmitters like norepinephrine (NE), 5hydroxytryptamine (5HT) and dopamine (DA) in the brain. Approximately two-thirds of the depressed patients respond to the currently available drug treatments of 
tricyclic antidepressants, selective serotonin reuptake inhibitors and MOIs but the magnitude of improvement is still disappointing, and these drugs have unusual side effects, so the search for more effective drugs with fewer side effects is on.

Ondansetron a 5HT3 antagonist, is commonly used in treating vomiting due to chemotherapy drugs, post operative patients and radiation therapy. The primary site of action of ondansetron is the chemoreceptor trigger zone (CTZ). Side effects such as headache and gastrointestinal upsets are relatively uncommon. Granisetron, the experimental drug is a potent and highly selective 5-HT3 receptor antagonist. It has little or no affinity for other 5HT receptors, or dopaminergic, adrenergic, benzodiazepine, histamine or opioid receptors, a characteristic that is thought to underlie the favourable side-effect and safety profiles of the drug. ${ }^{4}$

Clinical and preclinical studies have suggested that 5-HT3 receptors may be a relevant target in the treatment of affective disorders. 5-HT3 receptor agonists seem to counteract the effects of antidepressants in non-clinical models, whereas 5-HT3 receptor antagonists, such as ondansetron has antidepressant-like activities. ${ }^{5}$ Therefore the present study was undertaken to compare the antidepressant activity of ondansetron and granisetron in animal experimental models.

\section{METHODS}

\section{Selection of animals}

A total of 24 Albino mice of either sex, weighing around 25-30g and aged 3-4 months were employed in the present study. Pregnant and diseased animals were excluded from this study. They were exposed to alternate light and dark cycle for $12 \mathrm{~h}$ and had free access to food and water ad libitum. They were being procured from animal house of J.J.M. Medical College, Davangere.

The animals were randomly divided into 4 groups of 6 animals each and food was withdrawn $1 \mathrm{hr}$ before and $2 \mathrm{hr}$ after the administration of the drugs. The same groups of animals were subjected to both tail suspension and forced swim tests 60 min after drug administration with washout period of two weeks.

The animals were randomly assigned in the following groups and administered drugs as follows:

- Group 1: Control, normal saline $10 \mathrm{mg} / \mathrm{kg}$ i.p

- Group 2: Standard, fluoxetine $10 \mathrm{mg} / \mathrm{kg}$ i.p

- Group 3: Test drug 1 (TD1), ondansetron $2 \mathrm{mg} / \mathrm{kg}$ i.p

- Group 4: Test drug 2 (TD2), granisetron $0.5 \mathrm{mg} / \mathrm{kg}$ i.p

\section{Forced swim test}

This test was developed by Roger Porsolt ${ }^{6}$ and is based on the principle that forcing mice to swim in restricted space from which they cannot escape leads to a characteristic behaviour of immobility. Mice were individually forced to swim inside vertical plexiglass cylinder $\left(25 \times 10 \times 25 \mathrm{~cm}^{3}\right)$ filled with a water to a height of $15 \mathrm{~cm}$. Temperature of water was maintained at $23-25^{\circ} \mathrm{C}$. After an initial 2 minutes of vigorous activity by the mouse the duration of immobility was recorded during the next 4 minutes, in a total of 6 minutes test. A mouse is considered to be immobile when it remains floating in water making only minimum movements of its limbs. Duration of immobility was compared among all the 4 groups 60 minutes after drug adminis tration.

Following swimming sessions, the mice were dried with towel and placed in a cylinder under $60 \mathrm{~W}$ bulb for $15 \mathrm{~min}$ before returning to home cages.

\section{Tail suspension method ${ }^{7,8}$}

In this test, immobility was induced by suspending the mice by the tail. The method is based on the principle that a mouse suspended by tail above a fixed height of $50 \mathrm{~cm}$ from the ground shows alternate periods of agitation and immobility. Mice were suspended on the edge of a table with the help of an adhesive tape placed approximately 1 $\mathrm{cm}$ from the tip of the tail. Immobility time was recorded during a $6 \mathrm{~min}$ period. After an initial 2 minutes of vigorous activity by the mouse the duration of immobility was recorded during the next 4 minutes.

Duration of immobility was compared among all the 4 groups 60 minutes after drug administration. The immobility displayed by rodents, when subjected to an unavoidable and inescapable stress, has been hypothesized to reflect behavioral despair, which in turn may reflect depressive disorders in humans.

\section{Statistical analysis}

Statistical Analysis was carried out with SPSS Version 20 for Windows. Mean and Std deviation were calculated for continuous variables. Comparis on of four groups was done with One Way Analysis of Variance (ANOVA). Multiple comparisons done with Tukey's Post Hoc.

\section{RESULTS}

\section{Forced swim test}

There was significant reduction in immobility period in the animals treated with ondansetron and granisetron compared to control group and standard fluoxetine with $\mathrm{P}$ $<0.05$. Among both the test drug 2 granisetron showed marked reduction in mean immobility time of 10 seconds when compared to the test drug 1 ondansetron and fluoxetine which showed a reduction of immobility time of 24.17 seconds and 26.50 seconds respectively. The results of forced swim test have been shown in Table 1 and Figure 1. 


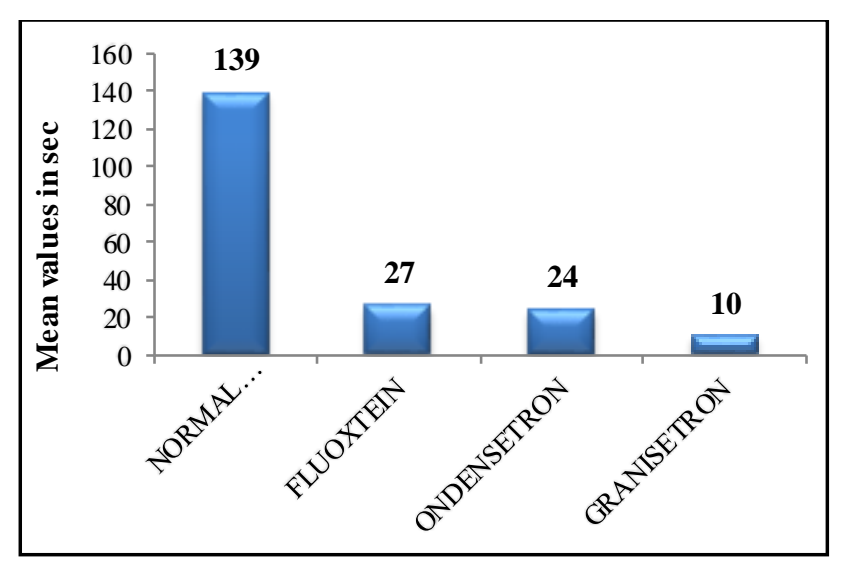

Table 1: Mean Duration of immobility observed in Forced Swim Test model.

\begin{tabular}{|c|c|c|c|c|}
\hline $\begin{array}{l}\text { Model 1- } \\
\text { Forced } \\
\text { Swim Test }\end{array}$ & $\begin{array}{l}\text { Mean } \\
\text { (Sec) }\end{array}$ & $\begin{array}{l}\text { Std. } \\
\text { deviation }\end{array}$ & ANOVA & P Value \\
\hline $\begin{array}{l}\text { Control- } \\
\text { Normal } \\
\text { Saline }\end{array}$ & 139.17 & 33.52 & \multirow{4}{*}{70.37} & \multirow{4}{*}{$\mathrm{P}<0.000$} \\
\hline $\begin{array}{l}\text { Standard- } \\
\text { Fluoxetine }\end{array}$ & 26.50 & 7.15 & & \\
\hline $\begin{array}{l}\text { TD1- } \\
\text { Ondensetron }\end{array}$ & 24.17 & 5.95 & & \\
\hline $\begin{array}{l}\text { TD2- } \\
\text { Granisetron }\end{array}$ & 10. & 2.73 & & \\
\hline
\end{tabular}

\section{Tail suspension model}

Table 1: Mean Duration of immobility observed in Forced Swim Test model.

\begin{tabular}{|lllll|}
\hline $\begin{array}{l}\text { Model 2- } \\
\text { tail } \\
\text { suspension } \\
\text { test }\end{array}$ & $\begin{array}{l}\text { Mean } \\
\text { (Sec) }\end{array}$ & $\begin{array}{l}\text { Std. } \\
\text { deviation }\end{array}$ & ANOVA & P Value \\
$\begin{array}{l}\text { Control- } \\
\text { normal } \\
\text { saline }\end{array}$ & 159.50 & 13.92 & & \\
\cline { 1 - 2 } $\begin{array}{l}\text { Standard- } \\
\text { fluoxetine }\end{array}$ & 117.00 & 13.81 & & \\
\cline { 1 - 3 } $\begin{array}{l}\text { TD1- } \\
\text { ondansetron }\end{array}$ & 76.67 & 9.27 & & \\
\cline { 1 - 2 } $\begin{array}{l}\text { TD2- } \\
\text { granisetron }\end{array}$ & 62.00 & 13.40 & & \\
\hline
\end{tabular}

Mean duration of immobility in ondansetron and granisetron treated groups of animals was significantly reduced compared to animals in control group and standard fluoxetine with $\mathrm{P}<0.05$. The results were more evident with granisteron when compared to ondansetron. The mean reduction of immobility time observed with granisetron was 62 seconds which was significantly lower than those with ondansetron and fluoxetine administered groups which showed a mean reduction of immobility time of 76.67 seconds and 117 seconds respectively. The results of tail suspension model have been shown in Table 2 and Figure 2.

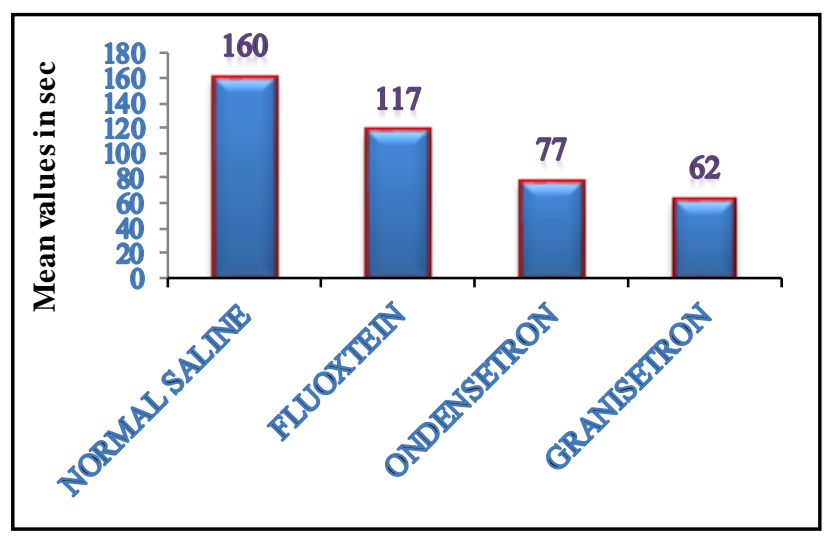

\section{DISCUSSION}

This study was evaluated to compare the antidepressant activity of drugs ondansetron and granisetron by using forced swim test and tail suspension test. These tests are quite sensitive and relatively specific to all major classes of antidepressant like TCA SSRI, MOAI and atypical antidepres sants. ${ }^{9,10}$ It has been argued that tail suspension is less stressfulthan forced swimming test and has greater pharmacological sensitivity. ${ }^{11}$ Antidepressant activity is indicated by the reduction in the duration of immobility i.e. lesser the duration more the potency. An increase in the serotonin concentration due to the blockade of the post synaptic 5-HT3 receptors can facilitate specific binding of Serotonin to other postsynaptic receptors such as 5-HT $1 \mathrm{~B}$, $5-\mathrm{HT}_{2} \mathrm{~A}$, and $5-\mathrm{HT}_{2} \mathrm{C}$, thereby aiding in serotonergic transmission which could be responsible for the antidepressant-like effect of these 5HT3 antagonists as many conventional antidepressants also possess affinity for central 5-HT3 binding sites. ${ }^{12}$ Ondansetron, is a carbazole derivative with shorter duration of action of about 3.9 hours and its congener granisetron, a indazole derivative has longer duration of action of about 9-11.6 hours and also it has low potential for drug-drug interactions. ${ }^{13}$

The results obtained in the present study indicate that granisetron, a 5-HT3 receptor antagonist posse a better antidepressant activity than ondansteron in rodent models predictive of antidepressant activity. In FST, both ondansteron and granisteron showed decrease in immobility duration when compared to control and standard drug fluoxetine. Granisteron showed better decrease of $10.33 \mathrm{sec}$ when compared to ondansetron $24.17 \mathrm{sec}$. Similar results were obtained in TST, where the granisetron treated group showed better results of $62 \mathrm{sec}$ immobility duration, when compared to $76.67 \mathrm{sec}$ in ondansetron.

\section{CONCLUSION}

Based on the present results, it is suggested that both granisetron and ondansetron, novel 5-HT3 receptor 
antagonists possess antidepressant activity with granisetron showing significant reduction in immobility time. Although 5-HT3 receptor antagonists share equivalent efficacies and safety profiles, there are differences among the agents in terms of pharmacokinetics, and duration of action. These results are further to be confirmed by animal studies with different experimental models for the evaluation of depression and by human clinical studies. If found effective granisteron can be promoted for use of PONV which is usually associated with depression.

\section{ACKNOWLEDGEMENTS}

Authors would like to thank the Post graduate students and Professors of Department of Pharmacology. Also would also like to extend my thanks to the animal house and Biostatistician of JJMMC Davangere.

Funding: No funding sources

Conflict of interest: None declared

Ethical approval: The study was approved by the Institutional Ethics Committee (No: JJMMC/IAEC/O42016)

\section{REFERENCES}

1. Fauci AS, Braunward E, Kaspler D, Loscalzo J. Harrisons Principals Of Internal Medicine $17^{\text {th }} \mathrm{Ed}$, Vol 2, New York: Mc Graw Hill; 2008:2717-2718.

2. Rechels on E. Pharmacology of Antidepress ants. Mayo Clinic Proceedings. 2011;76:516-27.

3. Madhav Sm. Epidemiological Study of Prevalence of Mental Disorders in India. Indian Journal of Community Medicine. 2001;26(4):198-200.

4. Srivastava SK. Anti-Depressant Activity of Ondansetron, A 5-Ht3 Antagonist, Indian J Pharmacol. 1998;30:411.

5. Cecile B, Alan LP, Adeline E, Bjarke E, Connie S, Nasser H. The Rapid Recovery Of 5ht. Cell Firing
Induced by The Antidepressant Vortioxetine Involves 5ht3 Receptor Antagonism. The International J of Neuropsychopharmacology. 2009;16:1115-27.

6. Porsolt RD, Pichon ML, Jalfre M. Depression: A New Animal ModelSensitive to Antidepres sant Treatments Nature. 1977;266:730-2.

7. Sanmukhani J, Anovadiya A, Tripathi CB. Evaluation of Antidepressant Like Activity of Curcumin And Its Combination With Fluoxetine And Imipramine: An Acute And Chronic Study. Drug Res. 2011;68(5):76975.

8. Santosh P, Venugopal R, Nilakash A. Antidepressant Activity of Methanolic Extract of Passiflora Foetida Leaves In Mice. Int $\mathrm{J}$ Pharm Pharm Sci. 2011;3(1):112-5.

9. Sterul, Chermat R, Thierry B. Simon P. The Tail Suspension Test: A New Method for Screening In Mice. Psychopharmacology (Berl). 1985;85(3):36770.

10. Porsolt RD, Bertin A, Jalfre M. Behavioural despair In Mice: A Primary Screening Test for Antidepressants. Arch Int Pharmacodyn Ther. 1977;229(2):327-36.

11. Thierry B, Steru L, Simon P, Porsolt RD. The tail suspension test: ethical considerations. Psychopharmacology. 1886;90(2):284-5.

12. Rajkumar R, Mahesh R. The auspicious role of the 5HT3 receptor in depression. A probable neuronal target? J Psychopharmacol. 2010;24:455-69.

13. Brunton LL, Chabner AB, Knollmann CB. Goodman and Gilman's, The Pharmacological Basis of Therapeutics, $12^{\text {th }}$ Ed, McGraw-Hill, New York. 2011:1345.

Cite this article as: Shah MJ, Geetha M, Rahul HD, Shashikala GH. A comparative study of the antidepress ant effect of ondansetron and granis etron on Albino mice. Int J Basic Clin Pharmacol 2017;6:2922-5. 